\title{
DEVELOPMENT OF FLIP CHART LEARNING MEDIA IN VIRUS MATERIALS FOR GRADE X HIGH SCHOOL STUDENTS
}

\author{
Aan Rinda Erviana ${ }^{1)}$, Devita Sulistiana ${ }^{2)}$, Maratus Sholihah ${ }^{3)}$ \\ 1,2,3 Islamic University of Balitar; Jl. Majapahit No.04, Telp. (0342) 813145 \\ Program Pendidikan Biologi, FKIP Universitas Islam Balitar, Blitar \\ e-mail: ${ }^{* 1}$ aanrindaervi@gmail.com, ${ }^{2}$ devitasulistiana@unisbablitar.ac.id, \\ ${ }^{3}$ maratussholihah@ unisbablitar.ac.id
}

\begin{abstract}
Based on preliminary observations that show that as many as $51,2 \%$ of 123 students stated that biology lessons were a difficult lesson. As many as $77,3 \%$ of students experience learning difficulties on virus material. Learning activities can not be separated from the use of learning media. This development aims to know the valid of flip chart learning media on virus material for high school students of class X. This research is a Research \& Development (R\&D) study using the Thiagarajan et all 4D development model, which is limited to the develop stage. This development research resulted in flip chart learning media through validation by a team of experts getting a total value of $80 \%$ with a valid category. Readability test results by students amounted to $94 \%$ with a very valid category. Flip chart learning media is worthy of being used as a learning medium on virus material.
\end{abstract}

Keywords: Flip Chart, Development Research, Virus

\section{INTRODUCTION}

According to Law Number 20 of 2003 concerning the National Education System Article 1 point 19, the curriculum is a set of plans and arrangements regarding the purpose, content, and material of the lesson as well as the methods used to guide the implementation of learning activities to achieve certain educational goals. 2013 Curriculum is an integrated curriculum as a concept can be said as a learning system or approach that involves several disciplines to provide meaningful and broad experience to students. Learning with the 2013 curriculum requires teachers to be able to provide innovative and creative learning in the hope that students are able to achieve learning goals. Learning activities in its application can not be separated from the use of learning media and 
JOSAR, Vol. 1 No. 1 March, 2018; p-ISSN: 2502-8251; e-ISSN: 2503-1155

Copyrights@ Balitar Islamic University, Blitar-Indonesia

https://ejournal.unisbablitar.ac.id/index.php/josar

teaching materials. Learning activities in its application can not be separated from the use of learning media and teaching materials. Learning media as one of the supporting facilities in effective learning and can increase student activity.

There are various learning media that can increase student activity in learning, which can be audio, visual and audio visual. Visual media can be in the form of print media such as images, posters, text and graphics. One of the printed learning media that contains images and important information in the form of flip chart learning media. Flip chart learning media is a learning media that can help students understand biological material easily.

Kustandi and Sutjipto (2013) suggest that learning media is a tool that can be used in the teaching and learning process and serves to clarify the meaning conveyed with the aim that learning is better and perfect. Media flip chart learning has several advantages, namely presenting a message in a concise and practical manner, can be used inside or outside the room, increasing student learning activities (Susilana \& Riyana, 2007). Other than that, flip chart learning media presents messages in stages and focuses on the material being taught.

Submission of material in biology learning needs to contain several real examples with the aim to facilitate students in learning and obtaining information easily. For example in viral material, this material requires sample images of the characteristics of viruses, the form of viruses, the structure of the virus body and the role of viruses for life so that material is easier for students to understand. The statement was supported by the results of preliminary observations from 123 students from 4 schools stating that as many as $51.2 \%$ of biology lessons were difficult lessons. As many as $77.3 \%$ of students had difficulty learning in virus material.

The use of flip chart learning media can be an alternative learning media used in supporting biology learning activities in the classroom. Based on the results of the observation, it was shown that flip chart 
JOSAR, Vol. 1 No. 1 March, 2018; p-ISSN: 2502-8251; e-ISSN: 2503-1155

Copyrights@ Balitar Islamic University, Blitar-Indonesia

https://ejournal.unisbablitar.ac.id/index.php/josar

learning media had never been used as a medium of learning in schools. The results of interviews with biology teachers stated that the media stated that the learning media used for the biology learning process used LCDs and sample images. Biology teachers need innovative, creative learning media and with the development of flip chart learning media capable of providing new innovations in learning.

The development of flip chart learning media is supported by previous research conducted by Rimayati (2016), Ratnasari (2017), Rosita (2017). The results of the three studies indicate that flip chart learning media are suitable to be used as learning media. The purpose of the study was to determine the feasibility of flip chart learning media media on virus material for high school students of class $X$.

\section{RESEARCH METHODS}

The development of flip chart learning media in virus material for high school students in class $X$ uses quantitative and qualitative approaches. Quantitative data in the form of assessment scores from expert teams. Qualitative data in the form of input and suggestions from the expert team. The research design used was Research and Development (R \& D) with a development model using Thiagarajan 4D, which consisted of define, design and development without disseminate.

The research procedure begins with the stages of defining, designing and developing. The defining stage is done to find out the needs in the field and the products developed by conducting front end analysis, student analysis, task analysis and concept analysis. At the design stage that is done is compiling test instruments, compiling media, composing the format, the initial design of the product. The development stage is a process carried out to realize the design that has been formulated into a product that is feasible to be used through validation by a team of experts.

The product developed has a specification that is designed like a desk calendar or desk calendar in the form of print media in A4 paper with 
JOSAR, Vol. 1 No. 1 March, 2018; p-ISSN: 2502-8251; e-ISSN: 2503-1155

Copyrights@ Balitar Islamic University, Blitar-Indonesia

https://ejournal.unisbablitar.ac.id/index.php/josar

310 types of paper art paper. Writing in the product uses letters namely Times New Roman 12, Comic Sans MS 15, 16, 18, 13, Arial Black 14, 37, Segoe Script 14, 35. Media flip chart learning contains a summary of the material, images of various forms of the virus, the composition of the body of the virus, replication of the virus, and examples of images of viruses that are harmful in life and their explanations. The flip chart learning media is equipped with a crossword puzzle at the end of the flip chart.

Products that have been declared feasible by the expert team can be used for product testing. Product testing is done by readability tests by students. Instruments and data analysis techniques are as follows.

1. Research Instruments.

The research instrument used a validation questionnaire by a team of experts and student readability questionnaires.

2. Data Analysis Techniques

The data obtained from this study are qualitative data and quantitative data. Qualitative data is data in the form of input and suggestions from expert teams which are then analyzed descriptively, while quantitative data is data in the form of scores from expert teams and readability of students. Quantitative data were analyzed using a Likert scale with the following score criteria.

Score $5=$ Very Valid

Score $4=$ valid

Score 3 = Quite valid

Score 2 = Less valid

Score 1 = Very Less valid

(Sugiyono, 2015).

Calculate the percentage of assessment given by the expert team and the readability test of students using the following formula.

$N P=\frac{R}{S M} \times 100 \%$

Information : 
JOSAR, Vol. 1 No. 1 March, 2018; p-ISSN: 2502-8251; e-ISSN: 2503-1155

Copyrights@ Balitar Islamic University, Blitar-Indonesia

https://ejournal.unisbablitar.ac.id/index.php/josar

$\mathrm{NP}=$ Percentage sought

$\mathrm{R}$ = Scoring answer score

$\mathrm{SM}=$ Maximum score

The criteria for the validity of flip chart learning media are shown in Table 1.

Table 1. Criteria for the level of validity (Sugiyono, 2011).

\begin{tabular}{cc}
\hline Percentage (in percent) & Information \\
\hline $81-100$ & Very Valid \\
\hline $61-80$ & Valid \\
$41-60$ & Quite Valid \\
$21-40$ & Less Valid \\
\hline $0-20$ & Very Less Valid \\
\hline
\end{tabular}

Products that have been tested are evaluated and refined so that the products developed are in accordance with the learning needs and are suitable to be used as learning media in schools.

\section{RESULTS AND DISCUSSION}

The define phase is used to conduct front end analysis, student analysis, task analysis and concept analysis. The analysis is the basis for developing products that meet your needs. The front end analysis is used to find out the curriculum used in the school. The curriculum used is the 2013 curriculum. The results of student analysis show that students have different learning characteristics. Analysis of tasks carried out in learning is adjusted to $\mathrm{KI}$ and $\mathrm{KD}$. Concept analysis is to identify the main concepts that will be taught systematically, namely about virus material.

The design phase is to plan the product design that is developed in the form of flip chart learning media on virus material for class $X$ high school students. Product design is by presenting virus material tailored to the learning objectives. The choice of background on the product is made in contrast to the writing color of the product and background made different on each sheet by product sheet. 
JOSAR, Vol. 1 No. 1 March, 2018; p-ISSN: 2502-8251; e-ISSN: 2503-1155

Copyrights@ Balitar Islamic University, Blitar-Indonesia https://ejournal.unisbablitar.ac.id/index.php/josar

The Development Phase is the product development stage which was developed through validation by a team of experts namely material experts, media experts and linguists. The results of the validation by the expert team are shown in Tables 2, 3 and 4. The results of the readability test by students are shown in Table 5 .

Table 2. Results of Material Expert Validation

\begin{tabular}{|c|c|c|c|c|c|c|}
\hline \multirow{2}{*}{$\begin{array}{l}\mathbf{N} \\
\mathbf{0}\end{array}$} & \multirow{2}{*}{$\begin{array}{l}\text { Descript } \\
\text { ion }\end{array}$} & \multicolumn{3}{|c|}{ Score } & \multirow{2}{*}{$\begin{array}{c}\text { Percentage } \\
\text { in (\%) }\end{array}$} & \multirow[t]{2}{*}{ Category } \\
\hline & & $\begin{array}{c}\text { Materi } \\
\text { al } \\
\text { Expert } \\
1\end{array}$ & $\begin{array}{l}\text { Materi } \\
\text { al } \\
\text { Expert } \\
2\end{array}$ & $\begin{array}{c}\text { Materi } \\
\text { al } \\
\text { Expert } \\
3\end{array}$ & & \\
\hline 1. & $\begin{array}{l}\text { Fill in the } \\
\text { material }\end{array}$ & 18 & 14 & 18 & $83 \%$ & $\begin{array}{l}\text { Very } \\
\text { Valid }\end{array}$ \\
\hline 2. & $\begin{array}{l}\text { Presenta } \\
\text { tion } \\
\text { Aspect }\end{array}$ & 18 & 17 & 25 & $80 \%$ & Valid \\
\hline \multirow{2}{*}{\multicolumn{2}{|c|}{$\begin{array}{l}\text { Total Score } \\
\text { Total Score } \\
\text { Percentage } \\
(\%)\end{array}$}} & 36 & 31 & 43 & & \\
\hline & & $80 \%$ & $68 \%$ & $95 \%$ & & \\
\hline \multicolumn{2}{|c|}{$\begin{array}{l}\text { Score of } \\
\text { Average } \\
\text { Material } \\
\text { Experts }\end{array}$} & & $81 \%$ & & & $\begin{array}{l}\text { Very } \\
\text { Valid }\end{array}$ \\
\hline
\end{tabular}

Table 3. Results of Media Expert Validation

\begin{tabular}{|c|c|c|c|c|c|c|}
\hline \multirow[t]{2}{*}{ No. } & \multirow{2}{*}{$\begin{array}{c}\text { Descriptio } \\
\text { n }\end{array}$} & \multicolumn{3}{|c|}{ Score } & \multirow{2}{*}{$\begin{array}{l}\text { Percenta } \\
\text { ge in }(\%)\end{array}$} & \multirow{2}{*}{$\begin{array}{c}\text { Categor } \\
\mathbf{y}\end{array}$} \\
\hline & & $\begin{array}{c}\text { Media } \\
\text { Expert } \\
1\end{array}$ & $\begin{array}{c}\text { Media } \\
\text { Expert } 2\end{array}$ & $\begin{array}{c}\text { Media } \\
\text { Expert } \\
3\end{array}$ & & \\
\hline 1. & $\begin{array}{l}\text { Physical } \\
\text { condition }\end{array}$ & 8 & 10 & 9 & 90 & $\begin{array}{l}\text { Very } \\
\text { Valid }\end{array}$ \\
\hline 2. & $\begin{array}{l}\text { Letters } \\
\text { used }\end{array}$ & 8 & 10 & 7 & $83 \%$ & $\begin{array}{l}\text { Very } \\
\text { Valid }\end{array}$ \\
\hline 3. & $\begin{array}{l}\text { Clarity of } \\
\text { Selection } \\
\text { and Layout } \\
\text { of Images }\end{array}$ & 19 & 21 & 21 & $81 \%$ & $\begin{array}{l}\text { Very } \\
\text { Valid }\end{array}$ \\
\hline 4. & $\begin{array}{l}\text { Color } \\
\text { Selection }\end{array}$ & 7 & 10 & 8 & $83 \%$ & $\begin{array}{l}\text { Very } \\
\text { Valid }\end{array}$ \\
\hline
\end{tabular}


JOSAR, Vol. 1 No. 1 March, 2018; p-ISSN: 2502-8251; e-ISSN: 2503-1155

Copyrights@ Balitar Islamic University, Blitar-Indonesia https://ejournal.unisbablitar.ac.id/index.php/josar

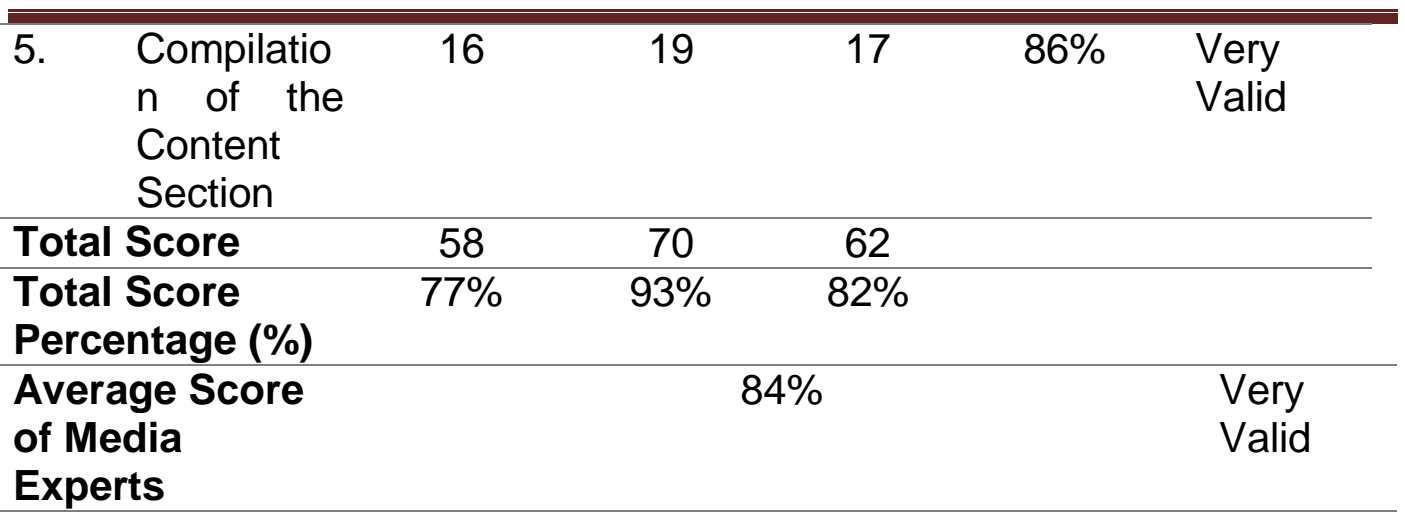

Table 4. Results of Language Expert Validation

\begin{tabular}{|c|c|c|c|c|c|c|}
\hline \multirow[t]{2}{*}{ No. } & \multirow{2}{*}{$\begin{array}{l}\text { Descripti } \\
\text { on }\end{array}$} & \multicolumn{3}{|c|}{ Score } & \multirow{2}{*}{$\begin{array}{l}\text { Percenta } \\
\text { ge in (\%) }\end{array}$} & \multirow[t]{2}{*}{ Category } \\
\hline & & $\begin{array}{l}\text { Langua } \\
\text { ge } \\
\text { Expert } \\
1\end{array}$ & $\begin{array}{l}\text { Langua } \\
\text { ge } \\
\text { Expert } \\
2\end{array}$ & $\begin{array}{l}\text { Langua } \\
\text { ge } \\
\text { Expert } \\
1\end{array}$ & & \\
\hline 1. & $\begin{array}{l}\text { Aspek } \\
\text { Bahasa }\end{array}$ & 18 & 23 & 16 & $76 \%$ & Valid \\
\hline \multicolumn{2}{|c|}{ Total Score } & 18 & 23 & 16 & $76 \%$ & Valid \\
\hline \multicolumn{2}{|c|}{$\begin{array}{l}\text { Total Score } \\
\text { Percentage (\%) }\end{array}$} & 72 & 92 & 64 & & \\
\hline \multicolumn{2}{|c|}{$\begin{array}{l}\text { Average Score } \\
\text { Linguists Experts }\end{array}$} & & $76 \%$ & & & Valid \\
\hline
\end{tabular}

Table 5. Readability Test Results

\begin{tabular}{|c|c|c|c|c|c|}
\hline No. & Description & & $\begin{array}{l}\text { Total } \\
\text { Score }\end{array}$ & Percentage & Category \\
\hline \multirow[t]{3}{*}{$\begin{array}{c}\text { Student } \\
1\end{array}$} & $\begin{array}{l}\text { Coverage } \\
\text { Material }\end{array}$ & of & 20 & $100 \%$ & Very Valid \\
\hline & Graphic design & & 21 & $84 \%$ & Very Valid \\
\hline & Linguistics & & 13 & $86 \%$ & Very Valid \\
\hline \multirow[t]{3}{*}{$\begin{array}{c}\text { Student } \\
2\end{array}$} & $\begin{array}{l}\text { Coverage } \\
\text { Material }\end{array}$ & of & 19 & $95 \%$ & Very Valid \\
\hline & Graphic design & & 22 & $88 \%$ & Very Valid \\
\hline & Linguistics & & 13 & $86 \%$ & Very Valid \\
\hline \multirow[t]{3}{*}{$\begin{array}{c}\text { Student } \\
3\end{array}$} & $\begin{array}{l}\text { Coverage } \\
\text { Material }\end{array}$ & of & 20 & $100 \%$ & Very Valid \\
\hline & Graphic design & & 23 & $92 \%$ & Very Valid \\
\hline & Linguistics & & 13 & $86 \%$ & Very Valid \\
\hline \multirow[t]{2}{*}{$\begin{array}{c}\text { Student } \\
4\end{array}$} & $\begin{array}{l}\text { Coverage } \\
\text { Material }\end{array}$ & of & 25 & $100 \%$ & Very Valid \\
\hline & Graphic design & & 20 & $100 \%$ & Very Valid \\
\hline
\end{tabular}


JOSAR, Vol. 1 No. 1 March, 2018; p-ISSN: 2502-8251; e-ISSN: 2503-1155

Copyrights@ Balitar Islamic University, Blitar-Indonesia https://ejournal.unisbablitar.ac.id/index.php/josar

\begin{tabular}{llccc}
\hline & Linguistics & 15 & $100 \%$ & Very Valid \\
\hline $\begin{array}{c}\text { Student } \begin{array}{l}\text { Coverage } \\
5\end{array} \\
\text { Material }\end{array}$ & 20 & $100 \%$ & Very Valid \\
\cline { 2 - 5 } & Graphic design & 25 & $100 \%$ & Very Valid \\
\cline { 2 - 5 } & Linguistics & 15 & $100 \%$ & Very Valid \\
\hline Total Score & $\mathbf{2 8 4}$ & & \\
\hline $\begin{array}{l}\text { Percentage of Total Score } \\
\text { in percent (\%) }\end{array}$ & $\mathbf{9 4 \%}$ & & Very Valid \\
\hline
\end{tabular}

Based on the results of expert validation and student readability, the development of flip chart learning media on virus material can be used as learning media. Assessment by a team of material experts, media and languages was $81 \%, 84 \%$ and $76 \%$ respectively. The average rating by the expert team is $80 \%$ with a valid category. Readability tests of students get an assessment of $94 \%$ with a very valid category. So that overall flip chart learning media on virus material is valid of being used as a learning medium. The same results are shown in research and development by Rosita (2017) entitled "Development of Flip Chart Biology Learning Media in Mushroom Materials" resulting in biology learning media that are valid to use. This is evidenced by the results of the assessment of material experts obtaining a percentage score of $89.1 \%, 77.5 \%$ of media experts and teacher perception results with a percentage of $91.4 \%$ with very good categories.

The products developed cannot be separated from the revisions that have been made according to the input and suggestions given by the expert team and examiners as a form of product evaluation so that the products developed are suitable for use. Product evaluation is done to improve the product developed, based on input from the examiner, which is added to $4.4 \mathrm{KD}$ "campaigning about the dangers of viruses in life, especially the dangers of AIDS based on virulence levels". Inputs and suggestions from the examiners are followed up as product enhancements so that the products developed are suitable to be used as learning media. 


\section{CONCLUSIONS AND SUGGESTIONS}

\section{A. CONCLUSION}

The results of the research data analysis showed that flip chart learning media in virus material for high school students in class $\mathrm{X}$ according to material experts was $81 \%, 84 \%$ media experts, $76 \%$ linguists, $94 \%$ readability. The average percentage of expert team assessment is $80 \%$ with a valid category so that it can be used as a learning media.

\section{B. SUGGESTIONS}

Suggestions that can be given is that it is better at the development stage to re-validate the test in order to get better results and are advised to develop until the disseminate stage.

\section{REFERENCES}

Kustandi C, Sutjipto B. 2013. Learning Media, Manual and Digital. Bogor: Ghalia Indonesia.

Ratnasari D. 2017. Development of Flip Chart Learning Media to Increase Earthquake Disaster Knowledge for Students at Cawas 1 Junior High School. Teacher Training and Education Faculty, Surakarta Muhammadiyah University, Surakarta. Essay. (Online). (http://eprints.ums.ac.id/54161/12/NASKAH\%20PUBLIKASI.pdf), accessed on May 6, 2018.

Rimayati IN. 2016. Media Development Flip Chart for Making Fashion Illustrations in Fine Arts Subjects at Mu'allimaat Muhammadiyah Madrasah Yogyakarta. Language and Arts Faculty, Yogyakarta State University, Yogyakarta. Essay. (Online). (http://eprints.uny.ac.id/29287/1/TAS\%20ITSNAINI\%20NURFAU ZYA\%20RIMAYATI.PDF), accessed on May 6, 2018.

Rosita R. 2017. Development of Flip Chart Biology Learning Media in Mushroom Materials for Class X High School Students. Teaching and Education Faculty, Jambi University, Jambi. Essay. (Online). (http://repository.unja.ac.id/1297/1/20/Riza\%20Rosita.pdf), accessed on May 6, 2018. 
JOSAR, Vol. 1 No. 1 March, 2018; p-ISSN: 2502-8251; e-ISSN: 2503-1155

Copyrights@ Balitar Islamic University, Blitar-Indonesia

https://ejournal.unisbablitar.ac.id/index.php/josar

Sugiyono. 2011. Quantitative, Qualitative Research and R \& D Methods. Bandung: Alfabeta.

Sugiyono. 2015. Management Research Methods. Bandung: Alfabeta.

Susilana R, Riyana C. 2007. Learning Media. Bandung: CV Wacana Prima. 